\title{
CONSTRAINTS TO AND OPPORTUNITIES FOR IMPROVING GOAT PRODUCTIVITY IN TABANAN REGENCY, BALI PROVINCE
}

\author{
DOLOKSARIBU, L., I. G. N. KAYANA, M. DEWANTARI, AND G. A. M. K. DEWI \\ Faculty of Animal Husbandry, Udayana University \\ e-mail: lindawati_doloksaribu@hotmail.com
}

\begin{abstract}
This study was undertaken to establish a database as consideration for improving goat production in Tabanan Regency. A survey was conducted from April to September 2018 on 38 smallholder goat farmers integrated with commodity plantations, owning 142 goats. Data were used to measure constraints to, challenges of, and opportunities for improving goat production, through a hybrid method of Strengths, Weaknesses, Opportunities and Threats and Analytic Hierarchy Process analyses. Problem priority faced was the competition between average numbers of 2.0 \pm 0.1 family labourers aged $38.8 \pm 2.1$ years who cultivated average $0.9 \pm 0.1$ hectare of commodity plantations integrated with flock size of $2.5 \pm 0.2$ goats per household. Goats were housed in battery systems and fed forage. About 33\% farmers had just sold all or portion of their goats due to the busy activity of clove and coffee harvesting in July-September and time consuming for cut and carry forage while commercial concentrates were not given to their goats. Recommendation taken was to providing Pennisetum purpureum silage as sustainable feed resource for goats thus improved the nutritious content of feed particularly during dry season where feed was limited or during harvesting and Bali Hindu ceremonies where family labourer was limited.
\end{abstract}

Keywords: assessing goat rearing, Tabanan Regency, SWOT and AHP analyses, limited family labourer, sustainable feed resource

\section{HAMBATAN DAN PELUANG PENINGKATAN PRODUKTIVITAS PETERNAKAN KAMBING DI KABUPATEN TABANAN, PROVINSI BALI}

\begin{abstract}
ABSTRAK
Studi ini dilakukan untuk pengadaan database sebagai dasar pertimbangan untuk meningkatan produksi kambing di Kabupaten Tabanan. Sebuah survey dilakukan sejak April hingga September 2018 terhadap 38 peternak kambing skala kecil yang terintegrasi dengan perkebunan, dengan total kambing sebanyak 142 ekor. Data digunakan untuk mengukur hambatan, tantangan dan kesempatan untuk meningkatkan produksi kambing, melalui metode hibrida dari Kekuatan (Strengths), Kelemahan (Weaknesses), Kesempatan (Opportunities) dan Ancaman (Threats) dan Analisis Proses Hirarki Analitik. Prioritas problem yang dihadapi adalah kompetisi antara rataan jumlah dari $2.0 \pm 0.1$ tenaker keluarga berusia $38.8 \pm 2.1$ tahun yang mengerjakan rataan $0.9 \pm 0.1$ hektar perkebunan yang berintegrasi dengan rataan jumlah kepemilikan $2.5 \pm 0.2$ kambing per keluarga. Kambing-kambing dikandangkan dengan sistem bateri dan diberi pakan di kandang. Sebanyak 33\% peternak baru saja menjual sebagian atau seluruh jumlah kambingnya oleh karena kepadatan aktivitas dari panen cengkeh dan kopi pada bulan Juli-September dan waktu yang diperlukan untuk potong dan beri atau cut and carry hijauan sementara konsentrat komersial tidak diberikan kepada kambingnya. Rekomendasi diberikan adalah untuk menyediakan silase Pennisetum purpureum sebagai sumber pakan yang berkesinambungan sekaligus meningkatkan kandungan nutrisi dari pakan khususnya pada musim kering dimana pakan terbatas atau musim panen dan upacara Hindu Bali dimana tenaker keluarga terbatas.
\end{abstract}

Kata kunci: penilaian pemeliharaan kambing, Kabupaten Tabanan, analisis SWOT dan AHP, tenaker keluarga terbatas, sumber pakan berkesinambungan 


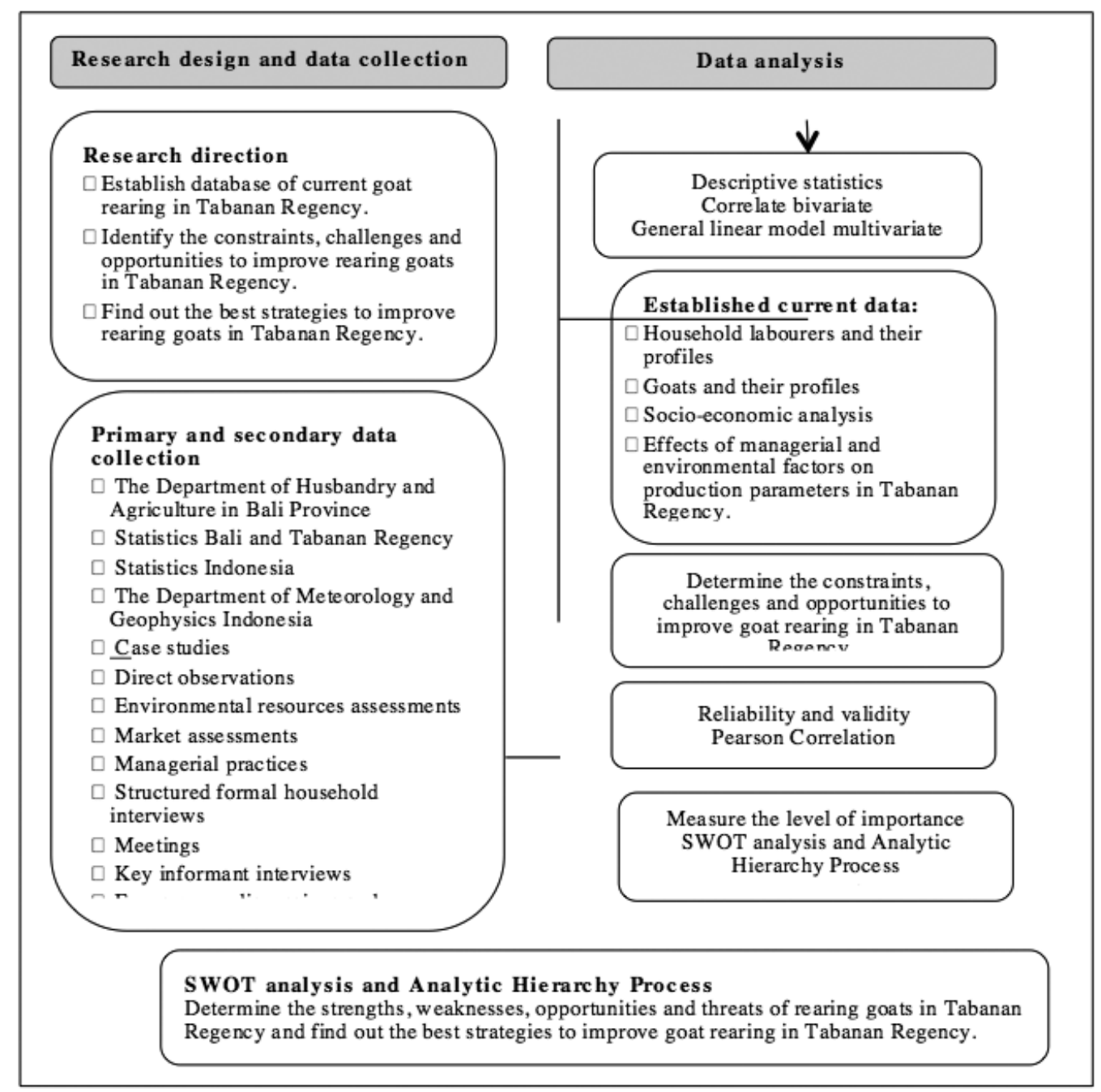

Figure 1. Proposed SWOT analysis and Analytic Hierarchy Process research framework in Tabanan Regency, Bali Province.

\section{INTRODUCTION}

Lack of baseline quantitative data on the reproductive and productive performance of goats in Tabanan Regency has limited our ability to identify factors that could lead to their improvement. Pupuan District was selected as the sampling area as it had the largest goat population among the districts in Tabanan Regency (BPS-Bali, 2018). Although Tabanan was designation regency for improvement of goat farming that was officially promulgated by the Indonesian Minister of Agriculture (Anonymous, 2015), this regency has 2,478 goats in 2018 and it had a 58\% less compared to 5,888 goats in 2013. There were 1,509 goats in Pupuan District in 2018 and it also had a $58 \%$ less compared to 3,571 goats in 2013 (BPS-Bali, 2018). Available literature presented little information on the current situation of their goat rearing under smallholder production systems in Tabanan Regency. Thus this study aimed to rectify this lack of data and to measure constraints to, challenges of, and opportunities for improving goat production in Tabanan Regency, through a hybrid method of Strengths, Weaknesses, Opportunities and Threats (SWOT) and Analytic Hierarchy Process (AHP) analyses (Kurttila et al., 2000; Doloksaribu et al., 2017).

\section{MATERIAL AND METHODS}

primary and secondary data on goat rearing under smallholder production systems in Tabanan Regency were summarized from various data resources (Figure 1). A purposive sampling procedure as described by Bryman (2016) was adopted to ensure that the selected householders comprised of goat farmers in Pupuan District. Pupuan District was selected as the sampling area as it had the largest goat population among the districts in Tabanan Regency. The combined data were analysed by using descriptive statistics, correlate bivariate and general linear model multivariate analyses using SPSS version 26 (Figure 1). 
Table 1. SWOT and AHP analyses considered for improving goat production in Tabanan Regency, Bali Province.

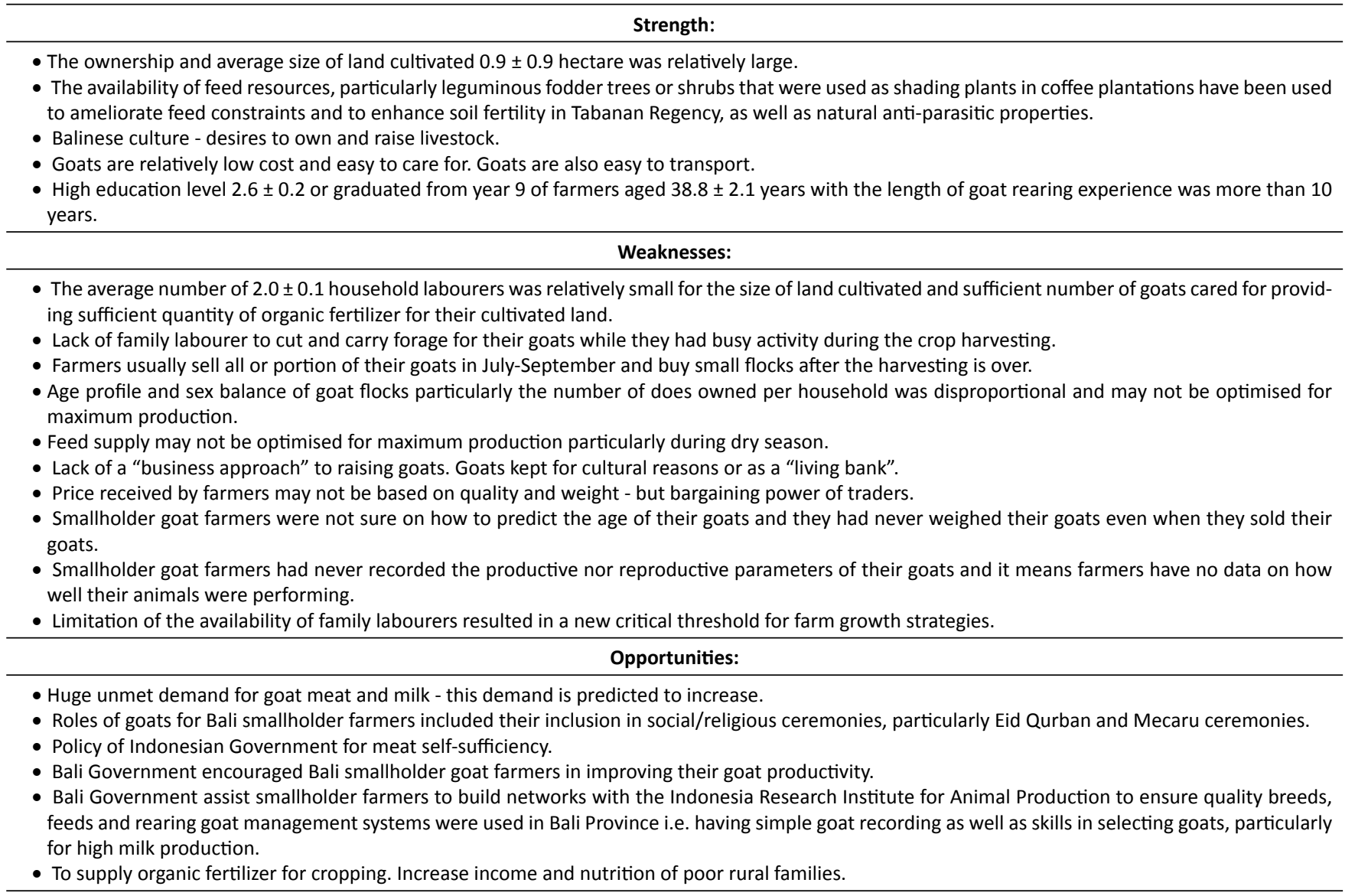

Threats:

- Foot and Mouth Diseases and endemic scabies diseases occurred due to lack of biosecurity of goat bought from outside.

- Cultural shift as more rural people move to urban areas to gain employment in business and tourist associated trade.

- Lack of capital and competition with other demands for farmer's attention (goats are a sideline enterprise).

The roles of Indonesian Government policies and practices were also reviewed and these were used in this study. The database of household labourers and their profiles, goats and their profiles as well as the environmental resources assessments, market assessments, managerial practices of the 38 smallholder farmers with their 142 goats, and 19 goat farmers who had just sold all or portion of their goats in this study were presented. Proposed SWOT analysis and Analytic Hierarchy Process research framework that involved interviewing 38 households with 142 goats from April to September in 2018 in Tabanan Regency is summarized in Figure 1. The strengths and weaknesses of the current reproductive and productive efficiency of goat farming under smallholder production systems in Tabanan Regency, as well as their socio-economic analysis and their opportunities and threats originating were determined using the SWOT matrix. The information obtained from the SWOT matrix was integrated into the AHP hierarchy to identify the most important factors as well as the optimum strategies for improving goat production (Figure 1) (Kurttila et al., 2000; Ho, 2008 and Saaty, 2008).

\section{RESULTS AND DISCUSSION}

The database of the current goat production in Tabanan Regency was mapped using a hybrid method composed of SWOT and AHP analyses. Goat production practices in Tabanan Regency were constrained by a variety of factors. A pairwise ranking method was employed to assess the detail of these problems that were associated with specific parameters of goat production. The result of this pairwise ranking analysis showed that, in most cases, the Pearson correlation ranked the factors influencing goat production such as: Size of land cultivated per household (ha) and Labourer ratio to flock size per household $(\mathrm{P}<0.05)$; Number of household labourers and Size of land cultivated per household (ha) $(\mathrm{P}<0.05)$; Number of household labourers and Flock size per household $(\mathrm{P}<0.05)$; while no significant correlation between Education level 
of the smallholder goat farmers and Size of land cultivated per household (ha) or Education level of the smallholder goat farmers and Gross margin per doe per household (IDR million) ( $\mathrm{P}>0.005)$. The identification of mechanisms, actions, innovations developed by 38 smallholder farmers with their 142 goats, for reducing their constraints and responding to their challenges, as well as the opportunities for improving their goat production are summarised in Table 1.

This study revealed that $33 \%$ smallholder goat farmers sold their goats prior the clove and coffee harvest time in July-September 2018, due to the competition of limited family labourers on doing the farming activity and rearing goats at the same time. Moreover, during the harvesting, Bali Hindus celebrate Galungan and Kuningan Days that are celebrated every 210 days besides other celebrations. It is common for Bali Hindus do a lot of preparation for the Galungan and Kuningan Ceremonies. By planting Pennisetum purpureum cv. Mott, farmers could learn how to make them silage. By feeding the silage to their goats, farmers could save time and energy at the peak of harvest time along with the preparation for Hindu Ceremonies. Farmers do not necessarily spend more time to cut roughage and feed their goats or sell their goats.

Only the farmers who kept rearing goats were able to sell goats prior Eid Qurban on the 21 ${ }^{\text {st }}$ August 2018 for the better price. Not only the farmers got more profit by selling more goats prior the Eid Qurban, they also got more goat manure as organic fertilizer to maintain high production of clove and coffee plantations. Doloksaribu (2017) revealed that a household labourer who handled 20 goats in a flock size of 39 goats including 10 does sold 37 goats annually that provided IDR 4,707,000 gross margin/doe/year. Similarly Singh et al. (2011) reported that large flocks of goats achieved higher profits than small and medium flock sizes. Guntoro (2012) recommended 25 to 28 goats per ha would be enough to produce goat manure as organic fertilizer to produce $2,450 \mathrm{~kg}$ coffee or $2,185 \mathrm{~kg}$ cacao annually. Nevertheless, cultivating $0.9 \pm 0.1$ hectare per smallholder household in Tabanan Regency could be one of the development strategies that will help in improving their income by fertilizing the land with organic fertilizer and selling more coffee and clove commodities along with more goats. Strategies for improvement of goat production in Tabanan Regency therefore could be achieved by:

\section{The proportional number of does and bucks in a flock.}

The availability of does and bucks in a flock that were well managed for their reproductive performance could be one of the development strategies that will help in improving their goat production. The presence of sufficient does and bucks in larger flocks generated more offspring that was then available for breeding stock for selection programmes (Peacock, 1996). Doloksaribu (2017) revealed that there should be a third of the flock was reproductive does.

\section{The proportion of labourers to flock size}

The number of household labourers to the number of goats managed per household that were well managed for their reproductive performance could be one of the development strategies that will help in improving their goat production. Doloksaribu et al. (2014) and Doloksaribu et al. (2015) revealed that to sustain positive GM(A-B) and GM/doe, households in Karangasem Regency had to have at least a flock of 8 productive does that produced 24 kids in 2 years; so they were able to plan to sell goats just prior to Eid Qurban for higher profits.

\section{Education level/knowledge/skill/experience of goats rearing management of smallholder goat farmers}

Improving the knowledge, experience and skill of the Bali smallholder goat farmers is critical in improving the efficiency of rearing goats. One of the ways to achieve those improvements is to improve their awareness of the particular feed resources available in neighbourhood to sustain feed particularly during harvest times, dry season and Bali Hindus ceremonies. This study revealed that farmers who substituted particular size of their coffee plantation to be planted with Pennisetum purpureum cv. Mott enabled them to sustain feed resource for their goats. In Karangasem Regency, as farmers grew crops they also fed their livestock with dagdag soup consisting of boiling water with rice pollard, salt, urea and chokos, cabbage, young jackfruits, sweet potatoes, cassava leftovers from their vegetable harvestings (Doloksaribu et al., 2014; Doloksaribu et al., 2015). This could be one of the development strategies that will help in sustainability of quantity and quality of feeds for their livestock, practical and convenient feed resources as well as reducing feed cost thus ensuring high income per household from goat production as well as their integrated farming.

\section{CONCLUSION}

Based on the assessing current goat production in Tabanan Regency particularly on the constrains to and opportunities for improving goat productivity, therefore, planting Pennisetum purpureum cv. Mott and improving farmer's skill to make the Pennisetum purpureum silage as sustainable feed resource were highly recommended. It is expected to improve goat 
productivity particularly during dry season where feed was limited or during harvest time where family labourer was limited. This is anticipated that smallholder farmers will not sell all or portion of their goats prior the harvest time of their crop plantations thus enable them to gain more profits by selling more goats prior Eid Qurban and selling more crop productions.

\section{REFERENCES}

Anonymous. 2015. The Minister of Agriculture's Decree No. 43/Kpts/PD.410/1/2015 officially promulgated designation areas for improving beef cattle, buffaloes, goats, dairy cows, sheep and pigs. Minister of Agriculture The Republic of Indonesia, Jakarta.

BPS-Bali. 2018. 'Badan Pusat Statistik Provinsi Bali, Statistics Bali Province. Bali in figures'.

Bryman, A. 2016. Social research methods, $5^{\text {th }}$ edn, Oxford University Press, Oxfords New York.

Doloksaribu, L. 2017. 'Improvement of rearing goats in Bali Province, Indonesia', $\mathrm{PhD}$ thesis, The University of Queensland, Queensland, Australia.

Doloksaribu, L., McLachlan, B. P., Copland, R. S. and Murray, P. J. 2015. 'Constraints to, challenges of, and opportunities for rearing goats in Bali Province. A case study: Rearing kids in Karangasem Regency', in The 3rd International Seminar on Animal Industry 2015 September 17th - 18th 2015, IPB International Convention Centre Bogor, Indonesia, vol. 3.

Doloksaribu, L., Murray, P. J,, Copland, R, S, and
McLachlan, B, P. 2014, 'Constraints to, challenges of, and opportunities for rearing goats in Bali Province. A case study: Rearing goats in Banjar Belulang, Sepang Village', in The 2nd Asian-Australasian Dairy Goat Conference April 25th - 27th 2014. The role of dairy goat industry in food security, sustainable agriculture production, and economic communities, IPB International Convention Centre Bogor, Indonesia, vol. 2, pp. 267-9.

Guntoro, S. 2012. The use of agriculture and industry by-products as feed for livestock, vol. 1, Agromedia Pustaka, Jakarta.

Ho, W. 2008. 'Integrated analytic hierarchy process and its applications - A literature review', in European Journal of Operational Research, 186, 1.

Kurttila, M., Pesonen, M., Kangas, J. and Kajanus, M. 2000. 'Utilizing the analytic hierarchy process (AHP) in SWOT analysis - a hybrid method and its application to a forest-certification case', Forest Policy and Economics, vol. 1, no. 1, pp. 41-52.

Peacock, C. 1996. Improving goat production in the tropics: a manual for development workers, Improving goat production in the tropics: a manual for development workers.

Saaty, T. 2008. Decision making with the Analytic Hierarchy Process, vol. 1.

Singh, S. P,, Singh, A. K. and Prasad, R. 2011. 'Economics of goat farming in Agra District of Uttar Pradesh'. Indian Research Journal of Extension Education, vol. 11, no. 3, pp. 37-40. 